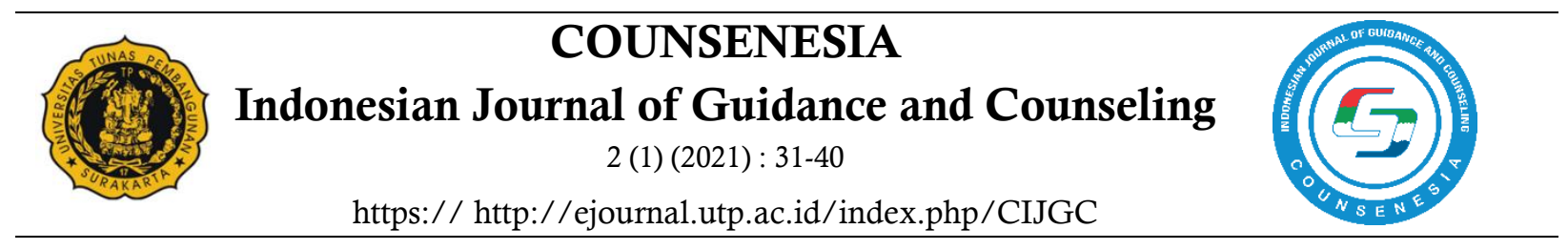

\title{
KONSELING INDIVIDUAL DENGAN PENDEKATAN REALITAS UNTUK MENGURANGI PERILAKU KONSUMTIF (STUDI KASUS PADA SISWA SEKOLAH DI MEDAN)
}

\author{
Rahmadi Tarmizi, Yeni Karneli ${ }^{2}$ \\ 1,2 Universitas Negeri Padang
}

Email: rahmaditarmizi@gmail.com

\begin{abstract}
Info Artikel
Abstrak

Riwayat Artikel

Diterima:

31 Maret 2021

Disetujui:

20 April 2021

Publikasi:

Juni 2021

Situasi Pandemi Virus Covid-19 berdampak terhadap aktivitas kehidupan manusia, dimana individu biasa beraktivias di luar rumah dan kini dibatasi untuk beraktivitas di luar rumah. Dampaknya individu belum siap dan yang paling dikhawatirkan adalah efek jangka panjang. Akibat lain yang ditimbulkan adalah munculnya perilaku konsumtif. Perilaku konsumtif merupakan perilaku dimana timbulnya keinginan untuk membeli barang-barang yang kurang diperlukan untuk memenuhi kepuasan pribadi. Pandemi covid-19 membuat masyarakat cenderung lebih konsumtif, akibatnya mereka membeli barang di luar kewajaran dan kebutuhan atau lebih di dorong oleh faktor keinginan. Studi kasus ini bertujuan untuk membantu siswi mengurangi perilaku konsumtif melalui konseling individual dengan pendekatan realitas. Penelitian ini menggunakan metode deskriptif melalui penelitian studi kasus (case study). Sasaran dalam studi kasus dengan judul konseling individual dengan pendekatan realitas untuk mengurangi perilaku konsumtif adalah seorang Siswa yang berada di Kota Medan. Teknik pengumpulan data adalah menggunakan observasi dan wawancara. Hasil yang diperoleh berupa kurangnya perilaku konsumtif mahasiswi melalui konseling individual dengan pendekatan realitas.
\end{abstract}

Kata Kunci: Perilaku konsumtif; konseling; pendekatan realitas

\begin{abstract}
The Covid-19 Virus Pandemic situation has an impact on the activities of human life, where ordinary individuals are active outside the home and now wake up to do activities outside the home. It seems that the individual is not ready and what worries most is the long-term effects. Another result is consumptive behavior. Consumptive behavior is behavior in which the desire to buy items that are not needed to fulfill personal satisfaction arises. The Covid19 pandemic makes people tend to be more consumptive, as a result they buy goods that are out of the ordinary and their needs or more are driven by desire factors. This case study aims to help students reduce consumptive behavior through individual counseling with a reality approach. This research uses descriptive method through case study research. The target in the case study entitled individual counseling with a reality approach to reduce consumptive behavior is a student who is in the city of Medan. The data technique uses observation and interviews. The results obtained from female student consumptive behavior through individual counseling with a reality approach.
\end{abstract}

Keywords: Consumptive behavior, counseling, approach to reality.

(C) 2021 Universitas Tunas Pembangun Surakarta

ISSN: 2746-3532 (Online) 


\section{PENDAHULUAN}

Pada era covid-19 masyarakat lebih banyak menghabiskan waktu di rumah bersama dengan gadget dalam menjalankan kehidupan sehari-harinya. Pandemi covid-19 membuat masyarakat cenderung lebih konsumtif, akibatnya mereka membeli barang di luar kewajaran dan kebutuhan atau lebih di dorong oleh faktor keinginan (Kasih, 2020). Sejalan dengan pendapat Maulana (2013), perilaku konsumtif merupakan perilaku dimana timbulnya keinginan untuk membeli barang-barang yang kurang diperlukan untuk memenuhi kepuasan pribadi. Hasil survei menujukkan wanita yang mayoritasnya adalah siswi dan mahasiswi yang mendominasi jumlah pembelian, jumlah penjualan, jumlah pengeluaran uang belanja, serta jumlah pemasukan di Tokopedia. Adapun rata-rata dari barang yang dibelanjakan terdiri dari produk kecantikan dan kesehatan, pakaian, fashion, aksesoris, dan gadget. Pencapaian persentasenya adalah 66,28\% sebagai masyarakat konsumtif dengan durasi belanja yang dapat mencapai 3 kali dalam seminggu. Sedangkan laki-laki yang mayoritasnya mahasiswa hanya berjumlah 33, 72\% (Rachmatunnisa, 2020). Dampak negatif perilaku konsumtif yaitu terjadinya pemborosan dan efisiensi biaya. Secara psikologis perilaku konsumtif menyebabkan seseorang mengalami kecemasan dan rasa tidak aman. Hal ini disebabkan individu selalu merasa adanya tuntutan untuk membeli barang yang diinginkannya akan tetapi kegiatan pembelian tidak ditunjang dengan finansial yang memadai sehingga timbulnya rasa cemas karena keinginannya tidak terpenuhi. Individu akan merasa rendah diri apabila ia tidak bisa membeli apa yang diinginkannya (Suyasa \& Fransisca, 2005).

Kemudian, sebagaimana yang dijelaskan dalam agama Islam, manusia dilarang untuk berperilaku konsumtif. Salah satu ayat Al-qur'an yang membahas tentang perilaku konsumtif disebutkan dalam surat Al-A'raf ayat 31, yang artinya:

"Hai anak cucu Adam! Pakailah pakaianmu yang indah tiap-tiap masuk masjid untuk beribadah dan Makan dan minumlah tetapi janganlah berlebih-lebihan. Sesungguhnya Allah tidak menyukai orang-orang yang berlebih-lebihan".

Selanjutnya profesionalitas seorang konselor dalam melaksanakan tugasnya sangatlah penting pada situasi pandemi covid-19 ini. Semakin konselor memiliki keterampilan dan kompetensi yang baik, maka individu akan dapat merasakan manfaat dari pemberian layanan konselor tersebut. Membantu permasalahan individu terkait dengan perilaku konsumtif dapat dibantu dengan menggunakan konseling individual dengan pendekatan realitas. Prayitno \& Amti (2004) mengemukakan bahwa konseling individu adalah sebagai pelayanan khusus dalam hubungan langsung tatap muka antara konselor dan klien. Dalam hubungan itu dicermati dan diupayakan pengentasan masalahnya, semampu dengan kekuatan klien itu sendiri. Dalam kaitan itu, konseling dianggap sebagai upaya layanan yang paling utama dalam pelaksanaan fungsi pengentasan masalah klien. Bahkan dikatakan bahwa konseling merupakan "jantung hatinya" pelayanan bimbingan secara menyeluruh. Apabila layanan konseling telah memberikan jasanya, maka masalah klien akan teratasi secara efektif dan upaya-upaya bimbingan lainnya tinggal mengikuti atau berperan sebagai pendamping. Konseling individual adalah layanan bimbingan dan konseling yang memungkinkan klien mendapatkan layanan langsung secara tatap muka dengan konselor dalam rangka pembahasan dan pengentasan permasalahan pribadi yang dideritanya (Sukardi \& Kusmawati, 2008). Konseling individu memiliki dua tujuan, yaitu tujuan umum dan tujuan khusus. Secara umum tujuan konseling adalah supaya klien dapat mengubah 
perilakunya ke arah yang lebih maju, melalui terlaksananya tugas-tugas perkembangan secara optimal, kemandirian, dan kebahagiaan hidup. Secara khusus, tujuan konseling tergantung dari masalah yang dihadapi oleh masing-masing klien (Hartono \& Soedarmadji, 2012).

Konseling realitas adalah salah satu pendekatan konseling yang berfokus pada masa sekarang dan masa depan (tidak pada masa lalu). Hal ini dikarenakan pandangan pendekatan realitas mengenai manusia bahwa masa lalu bersifat lampau dan tidak dapat diulang maupun diubah (Potabuga, 2020). Pendekatan realitas merupakan salah satu model pendekatan konseling yang sistemnya berfokus pada tingkah laku sekarang (Lumongga, 2011). Konseling realitas adalah pendekatan konseling dengan bentuk modifikasi tingkah laku, yang mana modifikasi tingkah laku ini difokuskan pada perasaan dan tingkah laku saat ini serta mengarahkan konseli untuk fokus perubahan yang membuatnya mampu keluar dari permasalahannya.Pada masa ini, terdapat banyak perubahan dan perkembangan yang terjadi seperti halnya teknologi dan komunikasi (Astutik, 2014).

Konseling realita merupakan suatu pendekatan yang difokuskan pada tingkah laku sekarang dan berfungsi untuk membantu konseli dalam menghadapi kenyataan serta memenuhi kebutuhan-kebutuhan dasar tanpa merugikan diri sendiri maupun orang lain. Konseling realita menekankan pada kekuatan-kekuatan, potensi, keberhasilan dan kualitas-kualitas yang positif dari konseli (Batubara, 2015). Glesser memandang manusi mampu memiliki potensi dan dorongan untuk belajar serta mampu mengambil keputusan bagi dirinya sendiri (Capuzzy, 2007; Corey, 2009).

Berdasarkan penelitian yang dilakukan Wulandari (2018) tentang pengaruh konseling individual teknik self-control terhadap gaya hidup konsumtif pada siswa harapan 1 medan, dengan hasil perubahan penurunan gaya hidup konsumtif siswa menurun setelah diberikan layanan konseling individual teknik self-control. Selanjutnya penelitian yang dilakukan Septiana (2019) tantang pengaruh bimbingan dan konseling individual terhadap perilaku konsumtif remaja, dengan hasil ada pengaruh yang siknifikan konseling individual terhadap perilaku konsumtif remaja sebayank 56,6\% dan 43, 4\% di pengaruhi oleh faktor lain.

Sesuai dengan latar belakang dan hasil penelitian di atas, maka penelitian dalam kajian studi kasus ini, memiliki tujuan sebagai berikut; a) menggambarkan perilaku konsumtif siswa, b) mengidentifikasi faktor-faktor yang mempengaruhi perilaku konsumtif seorang siswa, dan c) mengupayakan jalan keluar untuk memperbaiki atau mengurangi perilaku konsumtif seorang siswa.

\section{Landasan Teori}

\section{Mengurangi Perilaku Konsumtif}

Perilaku konsumtif adalah perilaku yang tidak lagi berdasarkan pada pertimbangan yang rasional, melainkan karena adanya keinginan yang sudah mencapai taraf tidak rasional lagi. Konsumen biasanya membeli barang karena barang tersebut bermerek, itu semua disebabkan konsumen ingin menaikkan status dilingkungan sekitarnya (Sumartono, 2002). Perilaku konsumtif tidak jauh dari kegiatan membeli. Pola hidup konsumtif dianggap sebagai pola hidup yang mengkhawatirkan karena meninggalkan pola hidup produktif. Konsumtif biasanya digunakan untuk menujuk pada perilaku konsumen yang memanfaatkan nilai uang lebih besar dari nilai produksinya untuk barang dan jasa yang bukan menjadi kebutuhan pokok (Tambunan, 2007). 
Perilaku konsumtif adalah tindakan membeli barang bukan untuk mencukupi kebutuhan tetapi untuk memenuhi keinginan, yang dilakukan secara berlebihan sehingga menimbulkan pemborosan dan inefisiensi biaya. Perilaku konsumtif terbentuk dikarenakan konsumtif itu sendiri sudah menjadi bagian dari proses gaya hidup. Sedangkan perilaku konsumtif itu muncul terutama setelah adanya masa industrialisasi dimana barang-barang di produksi secara massal sehingga membutuhkan konsumen yang lebih luas (Lestarina, dkk., 2017).

Para remaja cenderung selalu ingin memiliki barang-barang tersebut dan berlebihan dalam membeli atau mengonsumsi. Sikap atau gaya hidup remaja yang mengkonsumsi barang secara berlebihan dan tidak wajar inilah yang disebut konsumtif. Gaya hidup konsumtif yang banyak terjadi pada remaja putri pada umumnya hanya sebatas keinginan terhadap barang-barang tertentu dan belum tentu sesuai dengan kebutuhan. Selain itu, remaja putri yang lebih bersifat konsumtif terhadap pakaian dengan merek terkenal. Pakaian dengan merek terkenal dianggap jauh lebih berkualitas dan lebih mampu meningkatkan rasa percaya diri (Utami, dkk., 2020).

Munculnya perilaku konsumtif disebabkan oleh faktor eksternal dan internal. Adapun faktor eksternal yang berpengaruh pada perilaku konsumtif individu adalah kebudayaan, kelas sosial, kelompok referensi, keluarga dan demografi. sedangkan faktor internal yang berpengaruh pada perilaku konsumtif individu adalah motivasi, harga diri, pengamatan, dan proses belajar, kepribadian dan konsep diri, serta gaya hidup. Tuntutan zaman yang semakin maju mau tidak mau menyebabkan masyarakat juga turut mengikutinya. Karena asumsi publik menyatakan jika orang tidak mengikuti trend setter, ia dianggap katrok atau ketinggalan zaman. Hal itulah yang menjadikan siswa kebanyakan untuk mengikuti pola hidup yang konsumtif. Masa remaja akan terjadi perubahan dalam bentuk fisik, sosial, emosi, dan minat (Fardhani \& Izzati, 2013).

Faktor-faktor internal yang dominan membentuk perilaku konsumtif siswa yaitu: (a) Konsep diri, karena siswa yang selalu ingin membeli barang sesuai dengan bagaimana ia menilai dirinya sendiri, hal inilah yang menyebabkan responden menjadi konsumtif. (b) Gaya hidup, karena gaya hidup mereka yang selalu mengikuti trend zaman yang selalu berganti, hingga membuat mereka boros dan tidak ingat dengan menabung. Sedangkan Faktor eksternal yang membentuk perilaku konsumtif siswa yaitu: Kelompok referensi, karena mereka selalu terpengaruh dengan barang yang dibeli dan dimiliki oleh temannya, mereka merasa ingin sama dengan apa yang dimiliki oleh temannya (Estetika, 2017).

Menurut Kotler (2000), faktor yang mempengaruhi perilaku membeli yang memiliki andil dalam pembentukan perilaku konsumtif ada dua, yaitu faktor internal dan eksternal. Di dalam faktor internal terdapat faktor pribadi dan faktor psikologis, salah satu faktor internal terkait dengan usia yaitu remaja biasanya mudah terbujuk rayuan iklan dan cenderung boros dalam menggunakan uangnya. Faktor eksternal yang mempengaruhi perilaku konsumtif seseorang antara lain kebudayaan, merupakan keseluruhan pengetahuan manusia sebagai makhluk sosial, yang digunakan untuk memahami dan menginterpretasi lingkungan serta pengalamannya, kemudian menjadi pedoman bagi tingkah lakunya (Nuraeni \& Alfan, 2012)

Berdasarkan uraian di atas maka dapat disimpulkan bahwa perilaku konsumtif harus di kurangi agar tidak terjadi pola hidup yang mengkhawatirkan. Pola hidup saat ini tidak terlepas dari gaya hidup yang modern serta serba praktis yang didukung dengan perkembangan teknologi informasi yang pesat sehingga mempermudah 
remaja/siswa dalam memuaskan kepentingannya dengan salah memanfaatkan teknologi ini sehingga berdampak pada perilaku konsumtif mereka. Pada sisi lain, perilaku konsumtif ini merupakan membawa kenikmatan tersediri ataupun kepuasan secara fisik dan psikologis bagi para pelakunya, akan tetapi ini justru berdampak pada keuangan yang memboros, semestinya bisa di manfaatkan untuk keperluan lain yang lebih bermanfaat dan berguna untuk orang banyak.

Perilaku konsumtif ini sangat bisa dirubah dengan berbagai cara, yang terpenting dimulai dari keinginan diri sendiri dan tekat berupa komitmen yang tinggi untuk meninggalnya. Berikut ini beberapa cara yang bisa dilakukan untuk mengurangi perilaku konsumtif khususnya pada kalangan siswa, sebagai berikut:

1) Memprioritaskan Kebutuhan, memilih dengan seksama kebutuhan apa yang hendak di dahulukan, karena kebutuhan akan menjadi keperluan akan tetapi keperluan belum tentu menjadi kebutuhan. Oleh karena itu, didahulukan kebutuhan yang sangat atau paling dibutuhkan untuk di realisasikan.

2) Mengelola Keuangan, dengan mengatur pengeluaran keuangan tentu akan dimulai dari perencanaan sebelum melakukan, sehingga dalam perencanaan itu bisa betul-betul secara rasional dalam mengatur keperluan yang hendak untuk dibelanjakan. Mengelola keuangan memiliki pengaruh besar terhadap perilaku konsumtif siswa, dengan demikian dapat dikatakan bahwa mengelola keuangan dengan baik cukup berpengaruh terhadap perilaku konsumtif remaja, dimana ketika dalam mengelola keuangan meningkat maka perilaku konsumtif akan menurun (Imawati, dkk., 2013).

3) Mengontrol dengan menabung, ketika dorongan dari diri berperilaku konsumtif maka gerakkan diri untuk menabung, hal ini memang di perlukan tekat dan komitmen yang kuat dalam mengalihkan kedalam tabungan.

\section{Konseling Individual dengan Pendekatan Realitas}

Konseling individu adalah proses pemberian bantuan yang dilakukan melalui wawancara konseling oleh seorang ahli (disebut konselor) kepada individu yang sedang mengalami sesuatu masalah (disebut klien) yang bermuara pada teratasinya masalah yang dihadapi klien (Prayitno \& Amti, 2004). Konseling individual adalah layanan bimbingan dan konseling yang memungkinkan klien mendapatkan layanan langsung secara tatap muka dengan konselor dalam rangka pembahasan dan pengentasan permasalahan pribadi yang dideritanya (Sukardi \& Kusmawati, 2008). Konseling individual adalah pertemuan konselor dengan klien secara individual, dimana terjadi hubungan konseling yang bernuansa rapport, dan konselor berupaya memberikan bantuan untuk pengembangan pribadi klien serta klien dapat mengantisipasi masalah masalah yang dihadapinya (Willis, 2013).

Menurut Glasser (2000) Manusia digerakkan oleh kebutuhan-kebutuhan dasar yang asalnya bersifat genetik. Semua prilaku manusia mempresentasikan upaya untuk mengontrol dunia agar memenuhi kebutuhan-kebutuhan itu dengan sebaik-baiknya. Orang tidak pernah terbebas dari kebutuhan-kebutuhannya begitu terpenuhi, muncul kebutuhan lain. Kehidupan manusia adalah perjuangan konstan untuk memenuhi berbagai macam kebutuhan ini dan mengatasi konflik yang selalu muncul di antara mereka.

Pendekatan realitas adalah merupakan model terapi dalam konseling yang sistemnya difokuskan pada tingkah laku sekarang (Gerald, 2009). Terapi realitas adalah suatu sistem yang difokuskan kepada tingkah laku sekarang. Konselor berfungsi 
sebagai guru dan model serta mengkonfrontasikan klien dengan cara-cara yang bisa membantu menghadapi kenyataan dan memenuhi kebutuhan-kebutuhan dasar tanpa merugikan dirinya sendiri ataupun orang lain. Inti terapi realitas adalah penerimaan tanggung jawab pribadi, yang dipersamakan dengan kesehatan mental (Daud, 2019).

Dalam pendekatan realita ada choice theory (teori pilihan) dengan singkatan WDEP, yakni: W (Wants) keinginan, kebutuhan, dan persepsi; D (Direction and Doing) arah dan melakukan; E (Evaluation) mengevaluasi diri; dan P (Planning and Action) perencanaan dan tindakan. menggunakan WDEP akronim untuk menggambarkan prosedur kunci dalam praktek terapi realitas. Sistem WDEP terapi realitas dapat digambarkan sebagai Efektif, praktis, dapat digunakan, teori berbasis, lintas-budaya, dan didirikan pada prinsip manusia yang universal (Wubbolding dalam Corey, 2013). Sistem WDEP dapat digunakan untuk membantu klien mengeksplorasi keinginan mereka, hal-hal yang mungkin bisa mereka lakukan, peluang untuk evaluasi diri, dan desain rencana untuk perbaikan (Wubbolding dalam Corey, 2013)

Penggunaan konseling individual dengan pendekatan realita ini diharapkan agar individu dapat menentukan kebutuhannya secara prioritas sehingga berkurang prilaku konsumtif, melakukan komitmen dari dalam diri, mengevaluasi dirinya sendiri untuk dapat mengurangi perilaku konsumtif, dan merencanakan secara nyata berupa tindakan yang jelas dan terencana dalam mengurangi perilaku konsumtifnya.

\section{METODE}

Metode yang digunakan dalam penelitian ini adalah kualiatatif dengan jenis penelitian studi kasus (case study) dalam setting pelayanan bimbingan dan konseling. Penelitian ini dilakukan dengan tujuan untuk membantu mengurangi perilaku konsumtif seorang siswa. Studi kasus termasuk dalam penelitian analisis deskriptif, yaitu penelitian yang dilakukan terfokus pada suatu kasus tertentu untuk diamati dan dianalisis secara cermat sampat tuntas, sehingga dapat menguji ketepatan konselor dalam memberikan treatment kepada seorang siswi yang mengalami permasalahan perilaku konsumtif. Instrumen yang digunakan dalam penelitian studi kasus ini observasi dan wawancara. Sasaran dalam studi kasus ini adalah seorang Siswi yang berada di Kota Medan.

\section{HASIL DAN PEMBAHASAN}

FN merupakan salah satu siswi di sekolah SMA menengah ke atas di kota medan, FN terlahir dari keluarga yang serba kecukupan. Perilaku konsumtif FN sudah muncul mulai dari dulu, karena FN merasa tidak menganggu sehingga FN membiarkan begitu saja perilaku konsumtifnya. Ketika FN meranjak ke SMA FN mulai berpikir dan tersadar tentang perilaku konsumtifnya, sehingga FN mengalami kesulitan untuk memberhentikan perilaku konsumtifnya karena sudah menjadi kebiasaan.

Ketika FN memegang hp dan membuka aplikasi belanja digital sontak langsung perilaku konsumtifnya muncul, dimana dari pengakuan FN dia langsung tergoda dengan iklan-iklan yang bagus di aplikasi belanja tersebut. Kemudian ketika FN jalan-jalan santai ke mall dan tempat belanja lainnya FN juga mudah tergoda dengan prodak-prodak yang ditawarkan maupun dipajang di toko itu. Ketika rasa tergodanya itu muncul kemudian membeli maka terkadang perasaan bersalah dan penyesalan dari diri FN muncul dikarenakan tidak begitu dibutuhkan sekali barang yang dibeli.

Kesadaran dan penyesalahan FN ini tidak bertahan lama di dalam diri maupun benaknya, karena terkadang pikiran yang lain juga muncul dari benaknya seperti "toh bisa pakek juga di kemudian hari karena model seperti ini belum tentu ada di waktu lain, jadi 
di kumpulin dulu saja". Pengaruh pikiran FN seperti itu yang terlintas di benaknya sehingga rasa penyesalan dan kesadaran itu menjadi pudar dan terlupakan.

Dari hasil kajian konselor ketika proses konseling, kemudian wawancara, dan observasi langsung terhadap FN, sehingga tergambar sebagai berikut:

1) FN merupakan anak kesayangan dari kedua orang tuanya, sehingga apapun yang FN minta di turuti oleh orang tuanya.

2) Orang tua FN sibuk di kantor dan sedikit waktu bersama keluarga di rumah, bentuk kasih sayang orang tuanya FN dengan menuruti permintaannya.

3) FN tidak bisa mengatur uang sendiri, ketika FN di beri uang oleh orang tuanya pikiran yang terlintas di benak FN adalah kalau tidak membelikan ke barang maka mentraktir teman-temannya.

4) Ketika FN pulang kerumah setelah sekolah, FN hanya bersama asisten rumah tangganya dan kegiatan yang dilakukan FN juga tidak diawasi oleh orang tuanya, membuat FN bebas untuk melakukan kegiatan yang dia inginkan.

5) FN mengakui pengaruh perilaku konsumtifnya selain mudah tergoda melalui iklan-iklan, FN juga terpengaruh oleh lingkungan pertemanannya yang memandang bahwa FN merupakan orang berada sehingga menjadi tuntunan tersediri bagi diri FN untuk royal dan menjaga harga diri.

Ketika proses konseling individual dengan pendekatan realitas toeri pilihan WDEP, maka tergambar jawaban dari FN sebagai berikut:

\begin{tabular}{|c|c|c|}
\hline \multirow[b]{2}{*}{$\mathbf{W}$} & Konselor & FN \\
\hline & $\begin{array}{l}\text { 1. Apa yang kamu inginkan sekarang? } \\
\text { 2. Kamu sangat mengiginkan } \\
\text { meninggalkan perilaku konsumtif, } \\
\text { tetapi kamu sadar perlu ada pengontrol } \\
\text { yang kuat dari diri kamu sendiri? } \\
\text { Bagian dari fase ini konselor } \\
\text { melibatkan memunculkan komitmen } \\
\text { untuk konseling. Pertumbuhan pribadi } \\
\text { akan terjadi dan klien berkomitmen } \\
\text { untuk melakukan perubahan dalam } \\
\text { tindakan mereka (Wubbolding, dalam } \\
\text { Corey, 2013). }\end{array}$ & $\begin{array}{l}\text { 1. Saya sangat mengiginkan meninggalkan } \\
\text { perilaku boros saya yang tidak } \\
\text { menguntungkan sama sekali. } \\
\text { 2. Saya sangat sadar dan mempunyai tekat } \\
\text { yang kuat untuk meninggal itu pak. } \\
\text { Tekat saya benar-benar bulat siap untuk } \\
\text { menjalankannya. }\end{array}$ \\
\hline D & $\begin{array}{l}\text { 1. Bagaimana cara kamu melakukan tekat } \\
\text { kamu tersebut agar bisa terjalankan? }\end{array}$ & $\begin{array}{l}\text { 1. Saya melakukannya dengan mengontrol } \\
\text { diri saya terlebih dahulu kemudian } \\
\text { menyusun rencana seperti mengatur } \\
\text { uang dengan menabung. }\end{array}$ \\
\hline $\mathbf{E}$ & $\begin{array}{l}\text { 1. Seberapa besar penyesalan yang kamu } \\
\text { rasakan saat ini terhadap perilaku } \\
\text { konsumtif yang kamu lakukan? }\end{array}$ & $\begin{array}{l}\text { 2. Sayan sangat menyesal sekali, jika } \\
\text { seandainya perilaku itu bisa saya kontrol } \\
\text { tentu akan lebih bermanfaat } \\
\text { membagikan kepada orang yang lebih } \\
\text { membutuhkan. }\end{array}$ \\
\hline $\mathbf{P}$ & $\begin{array}{l}\text { 1. Rencana kongkrit apa yang akan kamu } \\
\text { lakukan setelah konseling ini ? }\end{array}$ & $\begin{array}{l}\text { 1. Saya akan menyisihkan uang yang } \\
\text { diberikan hari ini kedalam tabungan, } \\
\text { kemudian saya juga ingin bersedekah } \\
\text { agar supaya bisa lebih bermanfaat. }\end{array}$ \\
\hline
\end{tabular}

Setelah proses konseling yang dilakukan membawa perubahan yang signifikan terhadap FN dengan dilakukannya komitmen yang dibuatnya sendiri, proses konseling ini juga tidak cukup hanya sekali dan dua kali pertemuan akan tetapi perlu beberapa kali pertemuan sehingga sampai pada FN secara betul-betul meninggalkan perilaku 
konsumtifnya secara permanen. Kemudian FN juga bisa mengontrol dan memanagemen keuangannya sendiri secara penuh kesadaran dan komitmen yang kuat dalam melakukannya.

Teknik WDEP merupakan akronim dari Wants (keinginan), Direction (Arahan), Evaluation (penilaian), dan Planning (perencanaan). Teknik ini digunakan untuk membantu konseli menilai keinginan-keinginannya, perilakuperilakunya, dan kemudian merumuskan rencanarencana serta merepresentasikan elemen-elemen yang memaksimalkan keberhasilan rencana: mudah/sederhana (Simple), dapat dicapai (attainable), dapat diukur (measurable), segera (immediate), melibatkan tindakan (involving), dapat dikontrol (controlled), konsisten (consistent), dan menekankan pada komitmen (commited) (Darminto, 2007).

Untuk mencapai hasil akhir yang diharapkan berupa konsisten dan komitmen yang kuat di lakukan oleh klien, maka perlu kreatifitas dalam menerapkan teknik WEDP terhadap klien serta perlu kesabaran untuk terus mengikuti dan memantau setiap perkembangan klien setelah proses konseling berlangsung. Seperti FN ketika setelah proses konseling berlangsung maka penulis terus mengikuti dan memantau perkembangan yang dilakukan FN sampai dengan FN benar-benar mandiri dan bisa mengarahkan dirinya sendiri untuk tidak mudah berperilaku konsumtif.

Berdasarkan penelitian yang dilakukan oleh wulandari (2018) menggunakan konseling individual teknik self-control terhadap gaya hidup konsumtif pada siswa sma, dengan subyek 4 siswa yang memiliki gaya hidup konsumtif tinggi. Setelah melakukan konseling individual dengan teknik self-control maka menghasilkan penurunan yang singnifikan tinggi terhadap siswa tersebut dari pada sebelum dilakukan konseling individual dengan teknik self-control, dalam penelitian ini hanya menekankan terhadap intervensi berupa konseling individual dengan self-control tetapi tidak melakukan follow up lebih lanjut setelah melakukan penelitian. Berbeda dengan studi kasus yang penulis lakukan saat ini, dimana selain melakukan konseling individual dengan pendekatan realitas untuk mengurangi perilaku konsumtif siswa, melalui studi kasus ini dilakukan follow up serta pemantauan setelah dilaksanakan konseling individual sampai dengan klien berubah secara konsisten dan mandiri setelah proses konseling selesai.

Selanjutnya penelitian septiani (2019) menggunakan konseling individual terhadap perilaku konsumtif remaja, menghasilkan data bahwa gambaran perilaku konsumtif pada remaja di Madrasah Aliyah Negeri 2 Bandung Kabupaten Bandung ini memiliki nilai tengah 4,00. Artinya siswa dan siswi tersebut memiliki nilai perilaku konsumtif $50 \%$ diatas 4,00 dan 50\% dibawah 4,00. Hasil ini diperoleh dari perhitungan dengan menggunakan SPSS (Statistic Package of the Social Science). Kemudian bimbingan dan konseling individu memiliki pengaruh terhadap perilaku konsumtif sebesar 56,40\% dan 43,40\% dipengaruhi oleh faktor lain selain bimbingan dan konseling individu. Dalam penelitian ini menekankan intervensi berupa pemberian konseling individual, berbeda dengan penelitian yang dilakukan penulis dimana tidak hanya menekan pada intervensi berupa konseling individual, tetapi hasil akhir dengan kemandirian klien secara konsisten dan komitmen kuat untuk mengurangi perilaku konsumtif.

\section{PENUTUP}

Dari hasil studi kasus dapat disimpulkan secara umum setelah dilakukan konseling individual dengan pendekatan realitas untuk mengurangi perilaku konsumtif siswa memberikan dampak positif. Dampak yang diberikan yaitu, sebelumnya siswa belum bisa mengubah tingkah laku dirinya, sekarang setelah konseling, siswa sudah 
memiliki pemahaman dan keterampilan untuk mengubah tingkah laku dirinya sehingga mampu mengurangi perilaku konsumtif. Hal tersebut dapat dilihat dari sebelum diberikannya konseling individual dengan pendekatan realitas, dimana klien masih cenderung berperilaku konsumtif walaupun ada kesadaran dalam dirinya, tetapi belum ada penekanan komitmen dan kesadaran yang mendalam untuk melakukannya. Setelah proses konseling individual beberapa kali pertemuan membuat kesadaran dan komitmen yang kuat dari diri klien menjadi kuat untuk di lakukannya.

Keterbatasan penelitian ini adalah selain memakan waktu cukup lama untuk menyelesaikan permasalah klien sampai benar-benar terselesaikan, kemudian pemahaman dalam menggunakan konseling individual dengan pendekatan realitas WDEP sangat dituntut dengan baik guna memaksimalkan proses pengentasan masalah klien, dan penggunaan instrumen dalam pengambilan data hanya melalui wawacanra dan observasi. Rekomendasi penelitian berikutnya adalah dengan menggunakan lebih dari satu klien yang memiliki masalah sama sehingga akan lebih tertantang, kemudian menambah instrumen sehingga mempermudah mengumpulkan data dan informasi klien, serta menggunakan pendekatan realitas teknik WDEP terhadap masalah-masalah yang bervariatif lainnya.

\section{DAFTAR PUSTAKA}

Astutik, S. (2014). Pengantar bimbingan dan konseling. Surabaya: UIN Sunan Ampel Press.

Capuzzy, D \& Gross, D.R. (2007). Theory and practice of counseling and psychotherapy: Theories and Intervention. Upper Saddle River, New Jersey: Perason Prentice-Hal

Corey, G. (2013). Theory and practice of counseling and psychotherapy (9th Edition). California: Books/Cole.

Corey,G. (2009). Theory and practice of counseling and psychotherapy. Belmont CA:Brooks/Cole

Daud, A. (2019). Penanganan masalah konselig melalui konseling realitas. Jurnal AlTaujih Bingkai Bimbingan dan Konseling, 5 (1). Retrieved From https://ejournal.uinib.ac.id/jurnal/index.php/attaujih/article/view/757.

Estetika, M. (2017). Analisis faktor-faktor yang mempengaruhi perilaku konsumtif siswa perempuan kelas xii Ips. Jurnal Pendidikan dan Pembelajaran Khatulistiwa, 6 (6). Retrieved From http://jurnal.untan.ac.id/index.php/ipdpb/article/view/20352

Fardhani, P.R., \& Izzati, U.A. (2013). Hubungan antara konformitas dan perilaku konsumtif pada remaja (Studi pada siswa kelas xi sma trimurti surabaya). Charakter: Jurnal Penelitian Psikologi, 1 (2). Retrieved From https://jurnalmahasiswa.unesa.ac.id/index.php/character/article/view/1913

Glasser, W. (2000). Reality therapy in action. Jakarta: Rineka Cipta.

Hartono, \& Soedarmadji, B. (2012). Psikologi konseling. Jakarta: Prenada Media Group.

Imawati, dkk. (2013). Pengaruh financial literacy terhadap perilaku konsumtif remaja pada program Ips sma negeri 1 surakarta tahun ajaran 2012/2013. JUPE UNS, 2 (1). Retrieved From https://media.neliti.com/media/publications/13531-IDpengaruh-financial-literacy-terhadap-perilaku-konsumtif-remaja-pada-programips.pdf.

Kasih, A.P. (2020). Pakar unair: Pandemi covid-19 masyarakat cenderung lebih konsumtif. Kompas.com. Retrieved from 
https://edukasi.kompas.com/read/2020/07/17/161944571/pakar-unair-pandemicovid-19-membuat-masyarakat-cenderung-lebih-konsumtif

Kotler, P., \& Susanto. (2000). Manajemen pemasaran di indonesia. Jilid 1. Alih Bahasa Ancella A. Hermawan. Jakarta: Salemba Empat.

Lestari, N., dkk. (2017). Perilaku konsumtif dikalangan remaja. Jurnal Riset Tindakan Indonesia, 2 (2). Retrieved From http://jurnal.iicet.org/index.php/irti

Lumongga, N. (2011). Memahami dasar-dasar konseling dalam teori dan praktik. Jakarta: Kencana Prenada Media Group.

Maulana, R. (2013). Remaja dan perilaku konsumtif. Retrieved From http://sosbud.kompasiana.com/20 13/10/18/remaja-dan-prilakukonsumtif$\underline{599965 . h t m l}$

Nuraeni, H. G. (2013). Studi budaya di indonesia. Bandung: Pustaka Setia

Potabuga, Y.F. (2020). Pendekatan realitas dan solution focused brief therapy dalam bimbingan konseling islami. Al-Tazkiah, 9 (1). Retrieved from file:///C:/Users/user/AppData/Local/Temp/1833-Article $\quad$ Text-5389-2-1020201024.pdf

Prayitno \& Amti, E. (2004). Dasar-dasar bimbingan dan konseling edisi revisi. Jakarta: Rineka Cipta.

Rachmatunnisa. (2020). Survei Tokopedia. Detik.net. Retrieved from https://inet.detik.com/business/d-4872404/survei-tokopedia-dan-shopee-adukuat-mendominasi

Septiani, N. M. (2019). Pengaruh bimbingan dan konseling individu terhadap perilaku konsumtif remaja. Jurnal Bimbingan, Penyuluhan, Konseling, dan Psikoterapi Islam, 7 (2). $\quad$ Retrieved From https://jurnal.fdk.uinsgd.ac.id/index.php/irsyad/article/download/877/182.

Sukardi, D.K., \& Kusmawati, N. (2008). Proses bimbingan dan konseling di sekolah. Jakarta: Rineka Cipta.

Sumartono. (2002). Terperangkap dalam iklan: Meneropong imbas pesan iklan televisi. Bandung: Alfabeta.

Suyasa, P., \& Fransisca. (2005). Perbandingan perilaku konsumtif berdasarkan metode pembayaran. Phronesis, 7 (2).

Tambunan, A.P. (2007). Menilai harga wajar salam (stock valuation). Jakarta: PT Elex Media.

Utami, T., Rosra, M., \& Utaminingsih, D. (2020). Upaya mengurangi perilaku konsumtif melalui layanan konseling sebaya pada siswa. Jurnal Bimbingan Konseling $\begin{array}{lllll}(A L I B K I N), & 8 & (2) . & \text { Retrieved } & \text { From }\end{array}$ http://jurnal.fkip.unila.ac.id/index.php/ALIB/article/view/20409

Willis, S. S. (2013). Konseling individual, Teori dan praktek. Bandung: Alfabeta.

Wulandari, T., \& Lubis, Z. (2018). Pengaruh konseling individual teknik self-control terhadap gaya hidup konsumtif pada siswa kelas xi sma harapan 1 medan T.A 2017/2018. Jurnal Psikologi Konseling, 12 (1). Retrieved From https://jurnal.unimed.ac.id/2012/index.php/Konseling/article/download/12 $\underline{185 / 11773}$ 